\title{
Quality of Life of the Population: the Impact of Digitalization
}

\author{
Adigam Barlybaev ${ }^{1,2}$, Zulfiya Ishnazarova ${ }^{1,2, *}$ and Inna Sitnova ${ }^{1,2}$ \\ ${ }^{1}$ Institute of strategic research of the Republic of Bashkortostan, 453837 Sibay, Russia \\ ${ }^{2}$ Bashkir state University, Sibay Institute (branch), 453838 Sibay, Russia
}

\begin{abstract}
The article analyzes the impact of digitalization on the life population quality, identifies areas, identifies the positive and negative impact of digitalization on the qualitative characteristics of the population's life. The life quality is one of the important indicators of the level of development of society; it is a complex systemic integral characteristic of satisfaction with material and non-material factors of life of the population living in a certain territory. Since the environment and environmental conditions are constantly changing, various trends and patterns occur, the trends and requirements of our time, inevitably affect the life quality. One of such conditions, gaining momentum at the present time, is digitalization. Digitalization is the introduction of modern digital technologies in various spheres of life and production. Currently, in all types and levels of economic processes in the world and in individual countries, the so-called "digitalization" is gaining momentum - the active use of information and communication technologies. There is a need to accept digitalization as a universal process, adapt to it and use its levers for the best possible result for society. In nine areas, digitalization directly affects the life quality - the city, education, healthcare, economy, finance, information systems, infrastructure, business, and agriculture.
\end{abstract}

\section{Introduction}

The introduction of digital technologies is becoming a global trend, in some countries it began much earlier, e.g., in the USA, in the late 1990s, a conference was organized on assessing the digital economy at the government level. In Russia, the first forum in which issues of the digital economy was discussed was held in 2017 - the Eastern Economic Forum.

The issues of the digital economy and the assessment of the degree of its impact on the life quality are discussed in the works of foreign authors such as M. Castells, J. Stiglitz, A. Sen and J-P. Fitoussi, P. Gluckman and K. Allen and other scientists. Among domestic researchers studying digitalization in general, the works of Yu. Yu. Dashchenko, Babayeva A.B., Egorushkin T.N., Shvetsova S.A. should be noted, the impact of digitalization on the economy and regional development are considered in the works of V.G. Khalin, G.V. Chernova, O.V. Demidkina, K.O. Vishnevsky, Mukhametova A.D. The impact of the

* Corresponding author: zmsalikhova@mail.ru 
digital economy on employment is considered in the works of A.N. Kozyrev, A.A. Fedchenko, R.A. Mammaev, L.A. Borisov, the life quality is considered in the works of A.V. Keshelav, G.P. Litvintsev, B. Zh. Tagarova, V.V. Pevnev et al. [1-10].

Digitalization is especially important in order to enhance the life population quality, since, firstly, digitalization is directly introduced into the behavior and activities of people, starting from the use of the latest achievements of telecommunications in everyday life, continuing the use of IT technologies and modern equipment in production, agriculture, healthcare, education and other important areas, ending with the implementation of labor activities remotely and doing business only on the basis of the use of products of scientific and technological progress, including in microelectronics. Secondly, the results of the activities of many areas and spheres, ultimately, one way or another affect the life population quality, respectively, digitalization affects the quality and living conditions of the population, both directly and indirectly.

\section{Materials and Methods}

The article used the fundamental and applied works of domestic and foreign scientists who were involved in assessing the life quality, production and economic development, the reproductive potential of the region and the use of digital technologies [1-12]. The argumentation of the theoretical provisions and the conclusions obtained was performed on the basis of the application of general scientific methods (analysis, synthesis, comparison), specific methods (generalization and interpretation of scientific data, assessment of socialand-economic indicators and the development of the life population quality), methods of dialectical logic, statistics and sociology.

\section{Results and Discussion}

Assessment of the life quality includes a set of objective and subjective, private and general, single-level and multi-level indicators for measuring the degree of conformity of conditions and living standards of a person (population) to his/her (their) inner feelings of satisfaction with their lives.

The main factors that determine the life quality were proposed in 1961. by the United Nations Organization (Fig. 1) and include the spheres of activity and consumption: health, food consumption, housing conditions, employment, working conditions, education, social security, human recreation and leisure, human rights and non-food products [11-12]. 


\section{Factors determining the quality of life of the population}

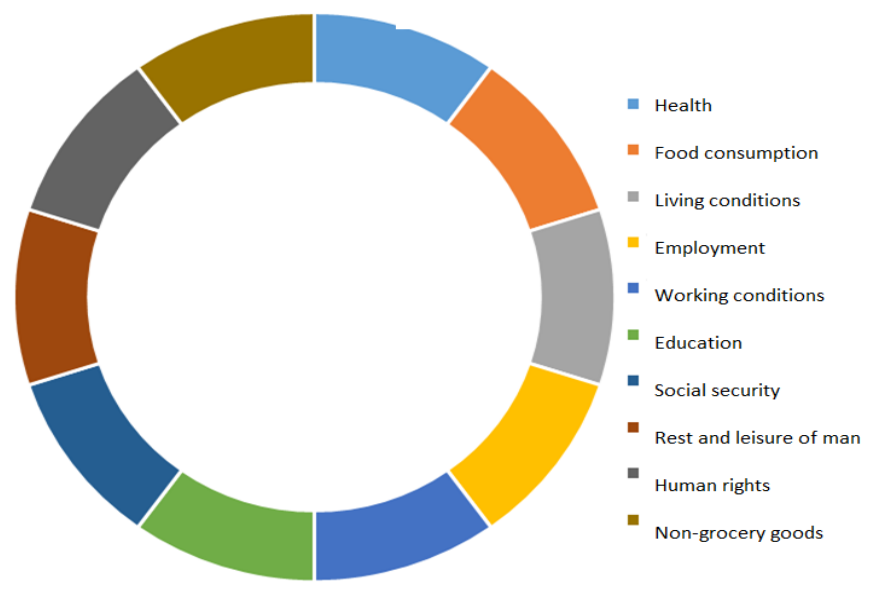

Fig. 1. Factors determining the life population quality

In the process of studying the methods for assessing the life quality, the following principles were formed:

1. An objective set of indicators for assessing the life quality may not always have a subjective reflection [5].

When assessing the life quality, both objective and subjective aspects are important. Objective - this is the level of education, health, environmental conditions, personal activity and others, subjective - this is a personal assessment of one's life, the psychological and emotional state of a person, expectations from the future and others.

2. The life quality is assessed at all levels of management: international, state, regional, municipal.

For instance, the most commonly used method at the government level is to estimate the gross domestic product (GDP). However, there is an assumption that GDP reflects a relatively narrow segment of society's activity (market production), rather than the life population quality.

Figure 2 shows that the Gross Domestic Product, as well as the gross profit of the economy and the gross mixed income of the Russian Federation, have a positive trend throughout the analyzed period [13-15]. However, Figure 3 shows that the real disposable cash income of the population of Russia from 2012 to 2016 had a negative trend, while this indicator most accurately reflects the characteristics of the well-being of the population. Real disposable cash income is the amount of cash that remains with a person minus mandatory payments. 


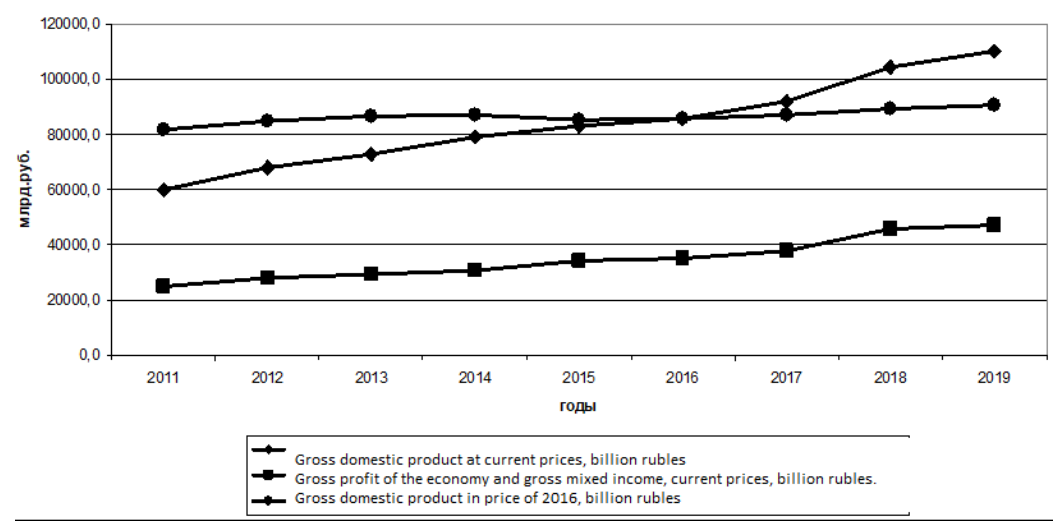

Fig. 2. Dynamics of gross domestic product, gross profit and gross mixed income, gross domestic product in the Russian Federation

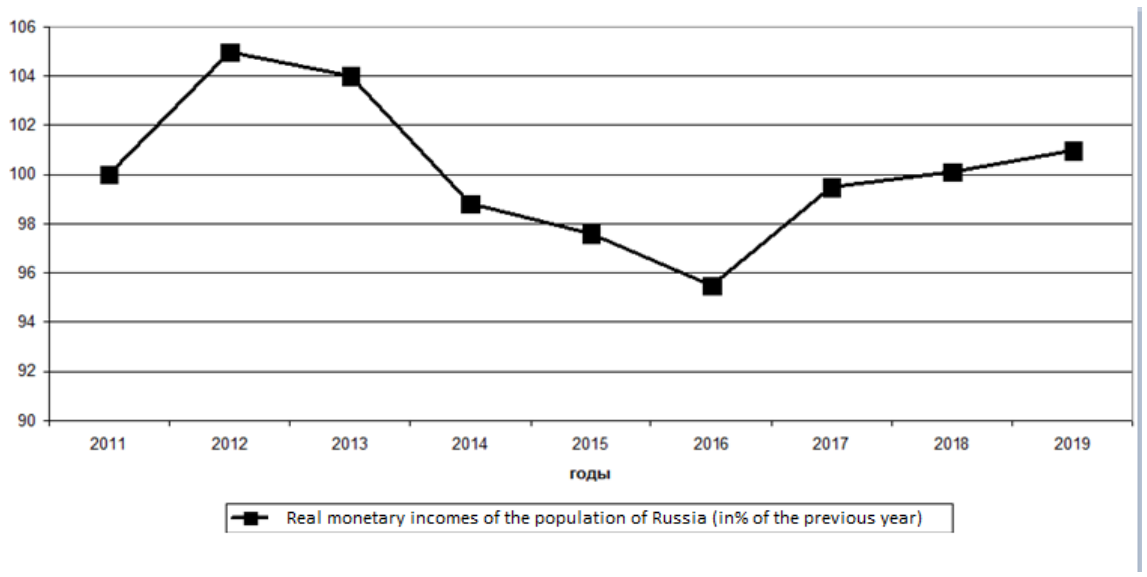

Fig. 3. Dynamics of real disposable cash incomes of the population of Russia

3. Different methods of measuring the life quality differ from each other in that they try to consider the part of it for the sphere of activity of which they are developed (medicine and health care, economic well-being, social status, psychological state, and others), often overlooking the indicators of other equally significant areas.

For instance, it may be seen in the concepts of standards and life quality (Standard of Living and Quality of Life), the methodology of the Economist Intelligence Unit (a division of The Economist Group), the new European development strategy "Europe 2020: a strategy for smart, sustainable and inclusive growth", the methodology of International Living (Ireland)" 19, methodology of the Organization for Economic Cooperation and Development on the Better Life Initiative innovation platform. These methodologies in the direction of "health" consider physical activity as the main indicator of the quality of human life [15-19].

The Human Capital Development Index (HDI) considers 3 important factors (standard of living, life expectancy and level of education), but does not consider, e.g., environmental aspects. Assessment of the life quality using the SF-36 questionnaire, which shows general well-being and those aspects of a person's life that are influenced by the state of health. It consists of 36 questions that are grouped into eight scales: physical functioning, roleplaying, bodily pain, general health, vitality, social functioning, emotional state, and mental health. The indicators of each scale are compiled in such a way that the higher is the value 
of the indicator (from 0 to 100), the better is the score on the chosen scale. The above are utilized to form two parameters: the psychological and physical components of health.

RIA Rating agency prepared a rating of the subjects of Russia in terms of life quality on the basis of official statistics. When calculating, they analyzed 70 indicators, which are combined into 11 groups. The Republic of Bashkortostan is in the 29th place in this rating (table 1).

Table 1. Rating of subjects of Russia by life quality

\begin{tabular}{|c|c|c|c|}
\hline $\begin{array}{c}\text { Place in } \\
2020\end{array}$ & Region & $\begin{array}{l}\text { Rating score } \\
\text { in } 2020\end{array}$ & $\begin{array}{c}\text { Place in } \\
2019\end{array}$ \\
\hline 1 & Moscow & 82.164 & 1 \\
\hline 2 & St. Petersburg & 80.634 & 2 \\
\hline 3 & Moscow region & 76.068 & 3 \\
\hline 4 & Republic of Tatarstan & 66.624 & 4 \\
\hline 5 & Belgorod region & 64.769 & 5 \\
\hline 6 & Krasnodar Territory & 63.714 & 6 \\
\hline 7 & Leningrad region & 61.6 & 8 \\
\hline 8 & Voronezh region & 61.046 & 7 \\
\hline 9 & $\begin{array}{c}\text { Khanty-Mansi Autonomous Okrug } \\
\text { - Yugra }\end{array}$ & 60.523 & 10 \\
\hline 10 & Kaliningrad region & 59.253 & 9 \\
\hline$\ldots$ & $\ldots$ & $\ldots$ & $\ldots$ \\
\hline 29 & Republic of Bashkortostan & 50.009 & 25 \\
\hline$\ldots$ & $\ldots$ & & $\ldots$ \\
\hline 81 & The Republic of Buryatia & 28.944 & 77 \\
\hline 82 & Jewish Autonomous Region & 28.188 & 83 \\
\hline 83 & Karachay-Cherkess Republic & 27.693 & 84 \\
\hline 84 & Transbaikal region & 26.889 & 82 \\
\hline 85 & Republic of Tyva & 17.506 & 85 \\
\hline
\end{tabular}




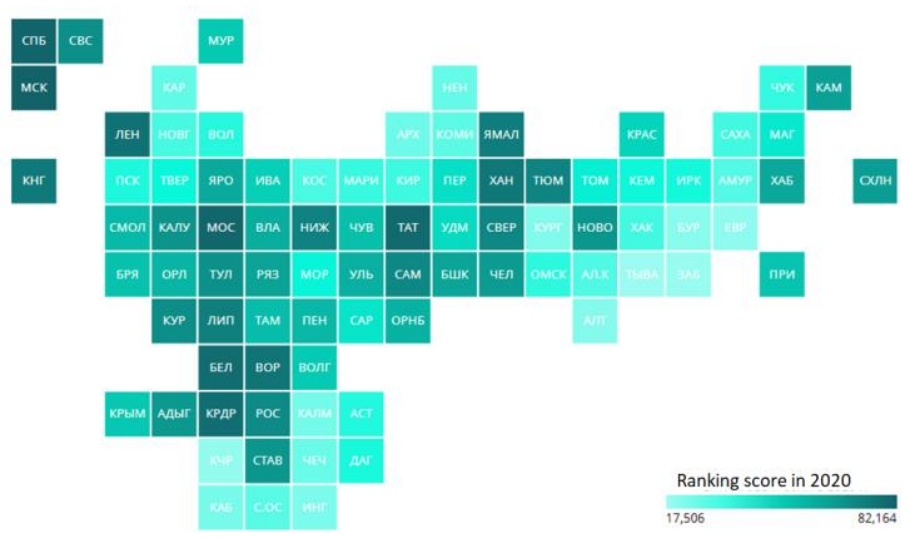

Fig. 4. Rating of Russian regions by life quality, compiled by the agency RIA Rating

The Mediakorset news portal compiled a rating of the life quality in cities and regions of the Republic of Bashkortostan - pursuant to open data from Rosstat (table 2).

The ranking of cities and districts is based on Rosstat data. It is compiled on the basis of figures characterizing the four main categories that determine the life quality: demography, health and the environment, education, labor and infrastructure. Within the framework of these blocks, indicators are collected both directly characterizing the life quality (e.g., the level of income, the number of places in kindergartens), and derivatives from them (birth rate, the share of the working-age population, etc.).

There are no separate indicators in the Rosstat database. In this case, the district was assigned the average value for the territories.

Table 2. Rating of the life quality in cities and municipal districts of the Republic of Bashkortostan

\begin{tabular}{|l|r|r|r|r|r|r|}
\hline \multicolumn{1}{|c|}{ Characteristics } & $\begin{array}{c}\text { Demogr } \\
\text { aphy }\end{array}$ & $\begin{array}{c}\text { Healthe } \\
\text { are and } \\
\text { environ } \\
\text { ment }\end{array}$ & $\begin{array}{c}\text { Educati } \\
\text { on }\end{array}$ & $\begin{array}{c}\text { Employ } \\
\text { ment } \\
\text { Infractu } \\
\text { re }\end{array}$ & $\begin{array}{c}\text { Ranki } \\
\text { place }\end{array}$ \\
\hline Ufa MD & 41 & 34 & 54 & 5 & 50 & 1 \\
\hline Neftekamsk & 16 & 45 & 25 & 30 & 127 & 2 \\
\hline Octyabrsky & 33 & 28 & 75 & 21 & 145 & 3 \\
\hline Duvansky MD & 36 & 65 & 44 & 79 & 83 & 4 \\
\hline Nurimanovsky MD & 68 & 39 & 107 & 51 & 43 & 5 \\
\hline$\ldots$. & $\ldots$ & $\ldots$ & $\ldots$ & $\ldots$ & $\ldots$ & $\ldots$ \\
\hline Ufa & 66 & 53 & 85 & 17 & 158 & 25 \\
\hline$\ldots$ & 70 & 32 & 176 & 79 & 140 & 58 \\
\hline Mishkinsky MD & 97 & 79 & 184 & 45 & 129 & 59 \\
\hline Kaltasinsky MD & 84 & 82 & 217 & 60 & 113 & 60 \\
\hline Ermekeyevsky MD & $\ldots$ & $\ldots$ & $\ldots$ & $\ldots$ & $\ldots$ \\
\hline
\end{tabular}

The digitalization of society is global in nature and is becoming an increasingly integral feature of economic development. And now it is becoming more and more important to determine the degree of influence of the widespread introduction of digital technologies on 
the living conditions of the population. It is necessary to distinguish the several directions of digitalization (application of digital technologies in various fields), the ones that are most clearly manifested are indicated in Figure 5 [17-19]:

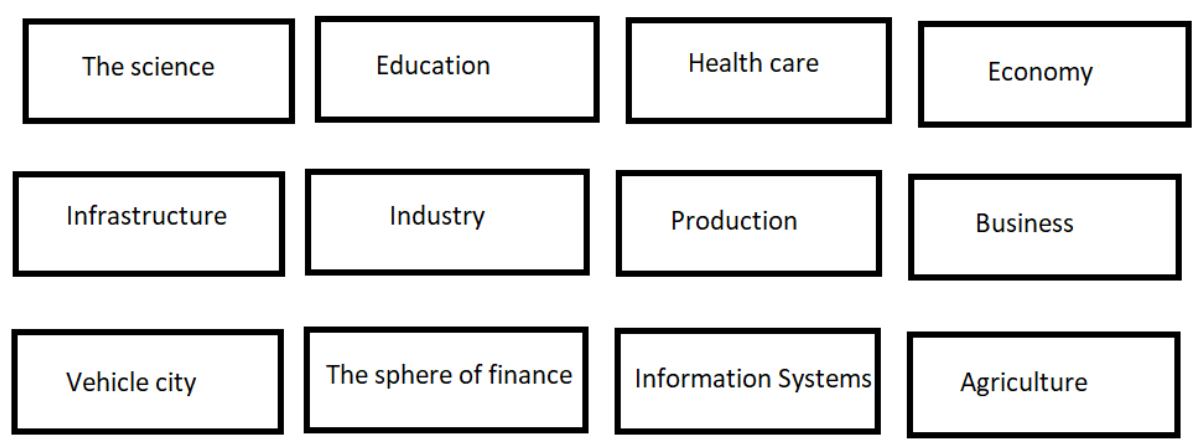

Fig. 5. Directions of digitalization of society

1. Digitalization of education, making education accessible, cost-effective and inclusive. The gradual digitalization of education has been going on for a long time, which makes it possible to increasingly increase the availability of education and training materials for everyone.

2.Digitalization of cities, which allows monitoring life in the city using cameras and sensors, predicting some events related to traffic, the environmental situation, crime, and so on. Currently, a new stage is being performed - the analysis of the collected data by artificial intelligence and the issuance of recommendations for improving various areas of the functioning of cities.

3. The digitalization of vehicles has been actively going on in the past ten years, occurring through the filling with digital maps, which contain information not only about roads, but also about their load, the presence of traffic jams and accidents, and the quality of coverage; an increase in the number of unmanned vehicles and so on.

4. Digitalization in science, which has been going on for a relatively long time, e.g., if in the middle of the 20th century scientists wrote articles in their writing and looked for data in paper versions of publications, now not only all this is done through computers, but scientific events no longer require personal presence, also new technologies in science are aimed at speeding up calculations and computations.

5.Digitalization in the field of finance, which makes it possible to simplify many financial transactions for both financial organizations themselves and enterprises, individual citizens. In the financial sphere, new technologies are, first of all, the so-called "blockchain" and non-cash payments, in addition, it is mobile banking, online shopping, remote payment and work.

6. Digitalization of information systems. The meaning of digitalization of information systems is so that a modern person does not have to strain and struggle with the human factor in the system. Documents may be made through the State Services application, the delivery service is actively working, and so on.

7. Digitization in agriculture, allowing to increase the productivity of this industry. The growing population of the planet needs a lot of resources. Therefore, the digitalization of agricultural processes is a serious and necessary step. Using the so-called "Internet of Things", which allows the exchange of data from servers, it is possible to competently manage raw materials, build "smart greenhouses" and deploy the "smart farms". This will help to optimize the amount of labor and more efficiently spend water, energy and other resources [17-19]. 
An even wider application of digital technologies and an increase in scientific interest have occurred with the emergence of complex epidemiological conditions from 2020 around the world. For instance, as noted by UNCTAD, since the global financial crisis of 2008 , over the past 12 years, the number of Internet users has grown from 1.6 to $4.1 \mathrm{bln}$ people, and the number of smartphones in use in the world has reached $3.2 \mathrm{bln}$. The share of Internet users among the world population over the same time increased from $23 \%$ to $54 \%$, the number of people using on-line shopping services doubled, and pursuant to the Department of International and Regional Cooperation of the RF JV for 2020, the volume of retail trade in the Internet has grown from 1 to 3.8 USD trln [8]. However, contrary to the belief that the pandemic has dramatically increased the number of remote jobs and functions is not entirely true. The tendency to transfer employees to a remote format has arisen for a long time. For instance, of the 11,000 jobs listed in the We Work Remotely (WWR) community database, $70 \%$ of employees say they have worked remotely for 3 years or more, and $42 \%$ of those surveyed say they have worked for 5 or more years. And only $11 \%$ of the answers were for those who switched to the remote format in the last six months - that is, just after the start of the pandemic [17-20].

Even before the onset of the coronavirus, it was predicted that by $2025,70 \%$ of the global workforce will work remotely for at least five days a month.

Digitalization has a direct positive impact on the life quality in nine areas (Fig. 6). However, all directions have an indirect impact on the life quality.

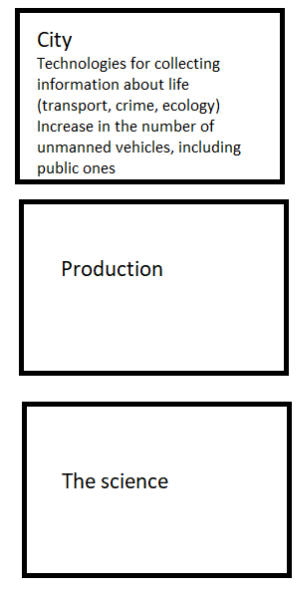

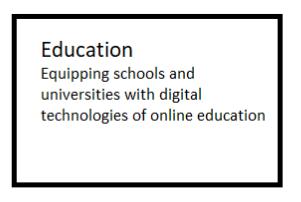
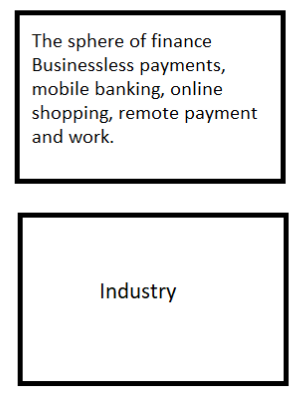
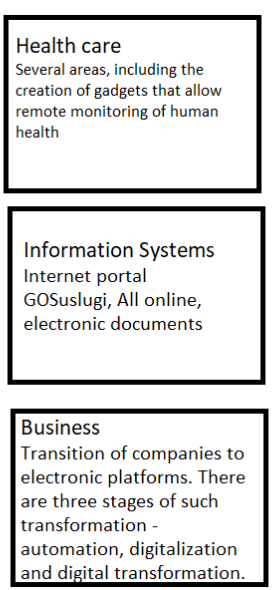

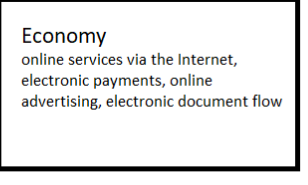

Infrastructure

Active use of interactive

maps, special applications for different segments of

the population and with

different types of activity

Agriculture

Smart greenhouses and smart farms, optimization of the labor force and more careful use of water energy and other resources

Fig. 6. The positive impact of digitalization on the population quality

Of course, like any other process, digitalization carries not only positive impacts, but also negative ones. Researchers at the Higher School of Economics highlighted cyberbullying against children, a lack of skills to use e-government services, a level of cybercrime, a lack of digital skills among teachers, and inequality in Internet use. 


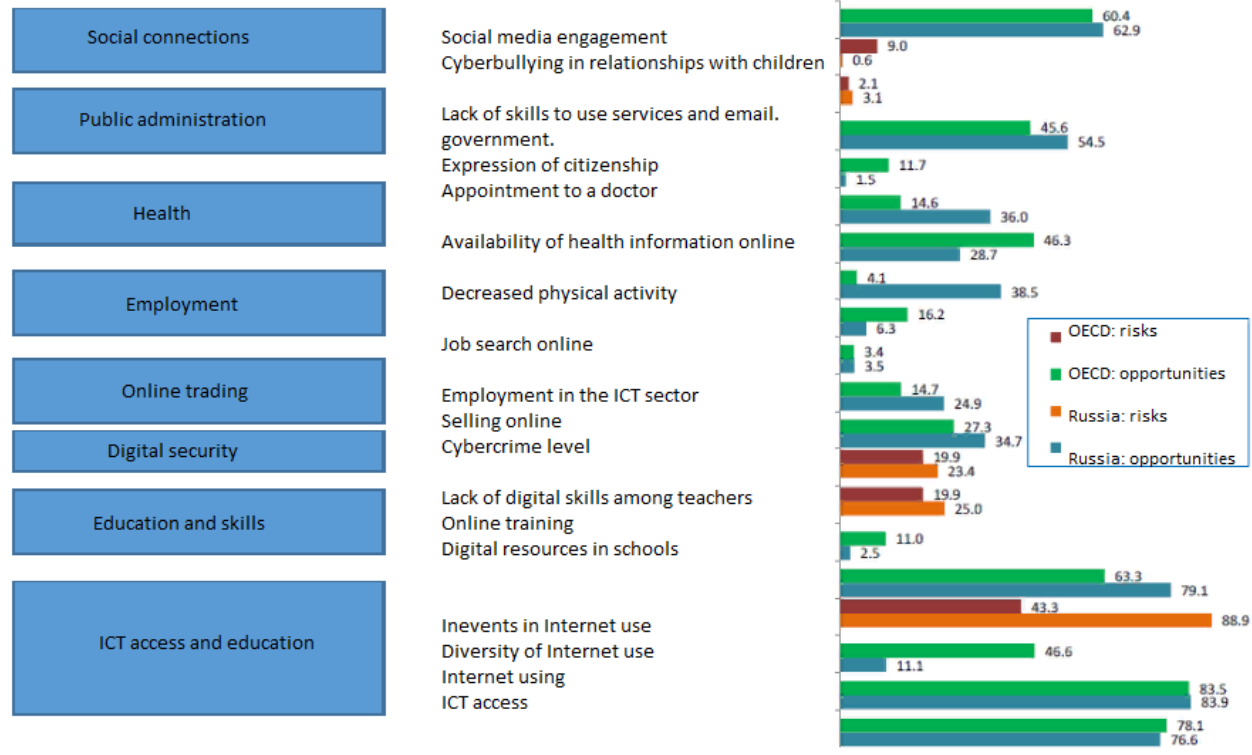

Fig. 7. Comparison of Russia and the OECD in terms of digital opportunities and risks: 2019

In addition, among the limitations of digitalization and negative influences, it is necessary to highlight the following:

1. Digital divide:

- in the world, $826 \mathrm{mln}$ schoolchildren do not have a computer (rural area, dysfunctional family);

- among countries with low income, more than $75 \%$ do not offer any form of distance learning;

- in Russia, $81 \%$ of the total population has access to the Internet - 118 mln people, respectively, $19 \%$ do not have access;

- half of Russians over 55 use the Internet, the remaining half do not.

2. Inequalities in the labor market, e.g., a digital revolution will take place in the next 20 years, as a result of which up to 50\% of work processes will be automated. Digitalization is changing the structure of the economy. Some professions disappear, others appear.

3. Influence on the physiological and psychosomatic state:

A conflict is being formed between the natural abilities of the human body and the new world of super-high-speed artificial systems.

Rise in general anxiety - the percentage of people who report ongoing security concerns is increasing (from $34 \%$ in 2014 to $41 \%$ in 2017).

Nevertheless, we cannot deny the development of this process throughout the world and in all spheres, its direct impact on the life population quality, somewhere positively, somewhere negative. Our task is to adapt to constantly changing conditions and try to use new conditions for good. Analysts of the Russian Association for Electronic Communications (RAEC) estimated the contribution of the digital economy to the Russian economy at $2.1 \%$ of GDP, and the contribution of the mobile economy at $3.8 \%$ of GDP. The total contribution is 4.35 RUR trln, i.e. $5.06 \%$ of GDP. 


\section{Conclusion}

A number of measures have been taken to support the active development of digitalization in Russia. For instance, the Decree of the President of the Russian Federation dated May 9, 2017 No. 203 adopted the Strategy for the Development of the Information Society in Russia for 2017-2030. Since 2018, Russia has been implementing the Digital Economy program [17-20], the purpose of which is to enhance the efficiency and competitiveness of the economy, social sphere and public administration, and departmental programs and projects are being implemented as well. The Russian Federation is actively working to maintain and further develop this new direction

Thus, digitalization carries the role of an accelerator of processes and quite seriously affects the life population quality and has several directions of manifestation. In assessing the life quality, it is also necessary to consider the degree of influence of the use of digital technologies on certain industries, infrastructure and social-and-economic processes.

The work was prepared at the expense of financial support for the implementation of the state task "Sustainable development of the Bashkir Trans-Urals as a unified socio-ecological-economic system" GANU "Institute for Strategic Studies of the Republic of Bashkortostan" for 2020 (head Suyundukov Y.T.)

\section{References}

1. F.F. Aidarbakov, A.A. Barlybaev, G.M. Nasyrov, I.A. Sitnova, U.A. Barlybaev, Studies on Russian Economic Development. 3, 291, (2019)

2. A.A. Barlybaev, I.A. Sitnova, I.M. Rahmatullin, V.T. Saitbatalova, Studies in Systems, Decision and Control. 316, 431 (2021)

3. Ad. A. Barlybaev, Az. A. Barlybaev, Z.M. Ishnazarova, I. A. Sitnova, D.U. Ishnazarov, E3S Web of Conferences. 1, 03062 (2020)

4. John F. Helliwell, Richard Layard and Jeffrey D. Sachs, World Happiness Report. UN Sustainable Development Solutions Network, 140 (2019)

5. D. Stiglic, A. Sen, ZH.-P. Fitussi, Neverno ocenivaya nashu zhizn': Pochemu VVP ne imeet smysla? Doklad Komissii po izmereniyu effektivnosti ekonomiki i social'nogo progressa, 113 (2016)

6. A.A. Fedchenko, N.V. Dorohova, E.S. Dashkova, Social'no-trudovye issledovaniya. 1, 24 (2021)

7. A.V. YAngirov, A.D. Muhametova, Ekonomika i upravlenie: nauchno-prakticheskij zhurnal. 5, 31 (2020)

8. A. D. Mukhametova, European Proceedings of Social and Behavioural Sciences, XXV, 2, 2581 (2019)

9. A.V. YAngirov, K.N. YUsupov, Regional'naya ekonomika: teoriya i praktika. 10, 75 (2014)

10. A.N. Kozyrev, Cifrovaya ekonomika i cifrovizaciya $v$ istoricheskoj retrospektive, https://medium.com/

11. A. Vichugova, Cifrovizaciya, https://www.bigdataschool.ru/wiki/

12. A. Timofeev, Vse onlajn: kak koronavirus pomog cifrovizacii, https://www.gazeta.ru

13. D.U. Ishnazarov, Z.M. Ishnazarova, U.A. Barlybaev, YA.T. Suyundukov, Regional'naya ekonomika: teoriya i praktika. 12, 2259 (2019) 
14. Z.M. Ishnazarova, D.U. Ishnazarov, YA.T. Suyundukov, Vestnik Altajskoj akademii ekonomiki i prava. 4(2), 200 (2020)

15. Itogi 2020 goda na rynke truda: cifry, fakty i tendencii, https://ccgb.ru/articles/itogigoda-na-rynke-truda

16. Ministerstvo cifrovogo razvitiya, svyazi i massovyh kommunikacij Rossijskoj Federacii, https://digital.gov.ru

17. Rosstat: Konsolidirovannye scheta, https://rosstat.gov.ru

18. I.A. Sitnova, Z.M. Salihova, D.U. Ishnazarov, Vestnik Bashkirskogo universiteta. 3, 918 (2015)

19. Cifrovizaciya i ee mesto v sovremennom mire. https://www.gd.ru/

20. Cifrovye tekhnologii i kiberbezopasnost' v kontekste rasprostraneniya COVID-19. Departament mezhdunarodnogo i regional'nogo sotrudnichestva SP RF, https://ach.gov.ru/ 